Chapter 5

\title{
Perfluorinated Organic Compounds and Polybrominated Diphenyl Ethers Compounds - Levels and Toxicity in Aquatic Environments: A Review
}

\author{
Monia Renzi \\ Additional information is available at the end of the chapter \\ http://dx.doi.org/10.5772/53835
}

\section{Introduction}

Organochlorine pesticides are well known by the scientific literature to be persistent in the environment, toxic for wildlife and potential dangerous for humans since the publication of the famous volume "Silent Spring" by Rachel Carson in 1962 [1]. Due to their massive industrial production and commercialization for various human purposes, these chemicals have reached concentrations in worldwide environments that are able to significantly affect terrestrial and marine wild species [2], remote world habitats [3] including the remote deep-sea [4], and protected species listed in the IUCN Red List of Threatened Species [5]. Actual concentrations are able to severely affect trophic webs [6] and top-predators [7; 8]. As animal, humans are not excluded by the effects of pollution and concerning these compounds, feeding represents the principal and worldwide diffuse exposure mechanism for human populations rather than inhalation and dermal contact $[9 ; 10 ; 11 ; 12]$. In spite of that, only in USA, chemical industry produces about 70,000 new products and organic chemicals accounted for the greatest share of production (364.2 million tons) in 1997 [13].

The continuous research of new substances able to cover the great request from engineering, chemistry, pharmaceuticals, medical, commercial and social activities led to the direct and indirect release in environment and the consequent exposure of living organisms to new compounds. Once released in the environment, new chemicals interact with the abiotic and biotic matrices producing mixture composed by pure chemicals which auto-interact, their metabolites and/or reaction and degradation by-products. These mixture are characterized by a progressive increase of complexity and by a clear geographical footprint with percentages of chemical composition that are dependent both by physico-chemical properties of 
compounds making the mixture and latitude/altitude of the geographical area considered [14]. Unluckily the effects induced by pure compounds on non-target species are frequently unknown at the time of their commercialization as well as possible by-products which are produced by the interaction with the environment. Usually, undesirable consequences of new synthesized chemicals are discovered many years later their distribution in commerce, often dramatically. This is the well-known case of the pesticide dichloro-diphenyl-trichloroethane (DDT) largely used to control malaria diffusion and publicized before 1970' as "the best friend of housewives in controlling pests".

Persistent organic pollutants (POPs) are characterized by molecular stability, high persistence due to the resistance to natural degradation processes derived by physical (i.e. temperature or photo-degradation), chemical (i.e. redox and acid-basic reactions, chemical interactions), and biological (i.e. metabolic or microbial deteriorations) aggressions. As reported by the European Community [15], to be classified as "persistent", chemicals must evidence a half-life in water superior than two months and in sediments/soils superior than six months.

POPs concentrate in environment for a very long time and, due to their vapor pressure $<1000$ $\mathrm{Pa}$ and a half-life $>2$ days in atmosphere, evidence long range transport reaching, also, remote areas [16]. These chemicals usually are low water soluble but evidence a great affinity towards lipids and tend to accumulate in sedimentary organic matter and biological tissues affecting the trophic web along which tend to biomagnificate [17]. Chemicals characterized by $\log \mathrm{K}_{\mathrm{ow}}>5$ and by a bio-concentration factor $(\mathrm{BEF})>5,000$ are considered "bioaccumulable" [15]. POPs are not biologically inert, on the contrary, they actively interact with physiological biochemistry of species inducing toxicity on wildlife species and humans.

Among POPs, perfluorinated organic compounds (PFCs) and polybrominated diphenyl ethers (PBDEs) are known as "emergent pollutants". PFCs and PBDEs are recently commercialized chemicals of particular ecotoxicological concern which are relatively little described by the literature [18]. PFCs and PBDEs increased levels during the latest decades both in environments and wildlife. Several studies have assessed them in a wide range of organisms [19], including humans [20; 21], from low latitude regions to remote areas, suggesting atmospheric transport of volatile precursor compounds and/or transport in ocean currents [22; 23; 24].

This chapter will focuses:

- general physico-chemical properties,

- sources, distribution dynamics, and environmental levels (in air, soil, water, sediment) with a particular attention on aquatic ecosystem;

- levels in wildlife tissues focusing evidences of bioaccumulation throughout the trophic web. Studies reporting levels both in red-list included species and foods at the basis of the human diet will be considered and included;

- phenomena of contamination in humans;

- evidences on toxicity based on results of ecotoxicological tests;

- international normative and guidelines developed to control considered chemicals 
The following paragraphs aims to summarized actual knowledge on PFCs and PBDEs principal characteristics including environmental levels and toxicity on biota.

\section{Physico-chemical properties of considered molecules}

PFCs and PBDEs include molecules characterized by a similar chemical formula but also by very different physico-chemical properties. As consequence of the structural dissimilarities, differences concerning environmental distribution dynamics, and levels in abiotic and biological matrices are observed among PFCs and PBDEs congeners. Furthermore, the ecotoxicological risk associated to the diffusion of these persistent organic pollutants could be notably dissimilar. In fact, physico-chemical properties of molecules influence possible adverse effects on non-target biological communities. In addition, observed toxicity is notably affected by the interaction among considered chemicals and environmental matrices caused by the photo-chemical deterioration and the production of metabolites during microbial biodegradation phenomena.

\subsection{Perfluorinated organic compounds (PFCs)}

Concerning chemicals of ecotoxicological interest, perfluorinated organic compounds (PFCs) are of particular emerging interest due their documented presence both in wildlife's tissues and human blood PFCs [25].

PFCs are anionic, and fluorine-containing surfactants (both soluble in water and oil) and are applied for a large industrial and commercial employment to produce surfactants, lubricants, paints, polishes, food packaging, and fire-fighting, foams propellants, agrochemicals, adhesives, refrigerants, fire retardants, and medicines [26; 27].

Their structure consisting of a fluorine atom with which all hydrogen atoms from the linearalkyl chain, which is a hydrophobic group, are replaced. Physico-chemical properties of PFCs favour the occurrence of long-range transport dynamics, as they are more volatile than chlorine or bromine analogues.

Among PFCs, perfluorooctanoic acid (PFOA) and perfluoroctanesulfonic acid (PFOS) represents the principal compounds of environmental concern.

Salts of perfluorooctanoic acid ( $\mathrm{PFOA}, \mathrm{C}_{8} \mathrm{HF}_{15} \mathrm{O}_{2}$ ) have been used as surfactants and processing aids in the production of fluoropolymers, and these salts are considered critical to the production of certain fluoropolymers and fluoroelastomers [28]. The functional chemical structure is $\mathrm{C}_{7} \mathrm{~F}_{15} \mathrm{COOH}$ and for this reason tends to behavior like an acid dissociating as follows: $\mathrm{C}_{7} \mathrm{~F}_{15} \mathrm{COO}^{-}+\mathrm{H}^{+}$.

Perfluorooctane sulfonate (PFOS; $\mathrm{C}_{8} \mathrm{HF}_{17} \mathrm{O}_{3} \mathrm{~S}$ even in this case it dissociates as follows: $\mathrm{C}_{7} \mathrm{~F}_{17} \mathrm{SO}_{3}^{-}+\mathrm{H}^{+}$) evidences an excellent chemical and thermal stability and is a chemical precursor for the synthesis of other molecules [26] such as fluorinated surfactants and pesticides (Abe and Nagase., 1982 in [29]). Perfluoroalkanesulfonate salts and 
perfluorocarboxylates are reported to be present in fire-fighting foam formulations, including aqueous film forming foams which are fire-fighting materials largely used by military bases and airports to face hydrocarbon fuel fires or to prevent the potential risk of fire [30; 31]. Moody and colleagues [32] reported for the 2001, an estimated PFOS annual production quantity in United States of America of 2,943,769 kg.

Principal PFOA and PFOS chemical properties are summarized in Table 1.

\begin{tabular}{lll}
\hline & PFOA & PFOS \\
\hline Extended name & Perfluorooctanoic acid & Perfluoroctanesulfonic acid \\
Other names & Perfluorooctanoate & 1-Perfluorooctanesulfonic acid \\
& Perfluorocaprylic acid & Heptadecafluoro-1-octanesulfonic acid \\
& FC-143 & Perfluoro-n-octanesulfonic acid \\
& F-n-octanoic acid & \\
\hline
\end{tabular}

\section{SUBSTANCE IDENTIFICATION}

\begin{tabular}{lll}
\hline CAS numb & $335-67-1$ & $1763-23-1$ \\
\hline Pubchem & 9554 & 74483 \\
\hline EC number & $206-397-9$ & $217-179-8$ \\
\hline
\end{tabular}

MOLECULAR PROPERTIES

\begin{tabular}{lll}
\hline Molecular formula & $\mathrm{C}_{8} \mathrm{HF}_{15} \mathrm{O}_{2}$ & $\mathrm{C}_{8} \mathrm{HF}_{17} \mathrm{O}_{3} \mathrm{~S}$ \\
\hline Molecular mass & $414.07 \mathrm{gmol}^{-1}$ & $500.13 \mathrm{gmol}^{-1}$ \\
\hline Boiling point & $189-192^{\circ} \mathrm{C}$ & $133^{\circ} \mathrm{C}(6$ torr $)$ \\
\hline Appearance $(25 \mathrm{C}, 100 \mathrm{kPa})$ & colorless liquid & white powder \\
\hline Vapor pressure & $4.2 \mathrm{~Pa}\left(25^{\circ} \mathrm{C}\right)$ & $3.31 \times 10-4 \mathrm{~Pa}\left(20^{\circ} \mathrm{C}\right)$ \\
\hline Melting point & $40-50{ }^{\circ} \mathrm{C}$ & $>400{ }^{\circ} \mathrm{C}$ \\
\hline Solubility in water & $3,400 \mathrm{mgL}^{-1}$ & $519 \mathrm{mgL}^{-1}\left(20 \pm 0.5^{\circ} \mathrm{C}\right)$ \\
\hline Solubility in other solvents & polar organic solvents & $680 \mathrm{mgL}^{-1}\left(24-25^{\circ} \mathrm{C}\right)$ \\
\hline Acidity (pKa) & $2-3$ [23] & $\mathrm{mgL}^{-1}$ (octanol) \\
\hline
\end{tabular}

RELATED RISKS

\begin{tabular}{lll}
\hline S-phrases & $\mathrm{S} 36, \mathrm{S37}, \mathrm{S39}$ & $\mathrm{S} 61$ \\
\hline R-phrases & $\mathrm{R} 22, \mathrm{R} 34, \mathrm{R} 52 / 53$ & $\mathrm{R} 61, \mathrm{R} 20 / 21, \mathrm{R} 40, \mathrm{R} 48 / 25, \mathrm{R} 64, \mathrm{R} 51 / 53$ \\
\hline
\end{tabular}

Table 1. Substance identification (extended names and international classification numbers), principal molecular properties, and related risks of PFOA (perfluorooctanoic acid) and PFOS (perfluoroctanesulfonic acid) are summarized in table. Specific references: record of PFOA were extracted from the GESTIS Substance Database from the IFA (last access on $5^{\text {th }}$ November, 2008). 


\subsection{Polybrominated Diphenyl Ethers (PBDEs)}

Polybrominated diphenyl ethers (PBDEs) are a class of organohalogen compounds used worldwide over the past three decades as chemical additives to reduce the flammability of common use products [34]. These chemicals were first introduced to the market in the 1960s and their global demand has increased rapidly since the end of the 1970s, due to the growing popularity of personal computers and other electronic equipment, to which they were added to improve fire safety [35].

Since '70 PBDEs were used as flame retardants in a wide range of common use such as cloths, foam cushions, polyurethane sponges, carpet pads, chairs, couches, electronic instruments including computer castings, and insulating materials [36].

In 2000, the industrial production of these chemicals has been esteemed to be around the 64,000 cubic tons per year. The $50 \%$ of this annual production was commercialized in America, while in Europe only 12\% [37].

Because of toxicity and persistence of PBDEs, these chemicals are included in the persistent organic pollutants (POPs) Reviewing Committee (www.pops.int) and their industrial production is to be eliminated under the Stockholm Convention.

Polybrominated diphenyl ethers are, apart from the oxygen atom between the phenyl rings, structurally similar to PCBs, consisting of two halogenated aromatic rings linked by an ether group. PBDEs chemical synthesis is performed by the diphenyl-ethers bromination in presence of dibromomethane as solvent. Diphenyl-ethers have 10 hydrogen atoms and each of them can be replaced by an atom of bromine. This reaction could produce 209 possible congeners, numbered from 1 to 209 in relation to the number of bromine atoms substituting hydrogen ones and their relative position within the molecule [38].

The general chemical formula for PBDE family is $\mathrm{C}_{12} \mathrm{H}_{(10-x)} \mathrm{Br}_{\mathrm{x}} \mathrm{O}$ (where $\mathrm{x}=1, \ldots, 10$ ).

In the United States, PBDEs are marketed with trade names: DE-60F, DE-61, DE-62, and DE-71 applied to penta-BDE mixtures; DE-79 applied to octa-BDE mixtures; DE 83R and Saytex 102E applied to deca-BDE mixtures.

The available commercial PBDE products are not single compounds or even single congeners but rather a mixture of congeners. Nevertheless, commercial mixtures are constituted by a little part of the 209 possible congeners due to the instability of a large part of them [39] which tend to quickly debrominate.

Three technical mixtures are available and commercialized and differ related to the bromination levels:

- Mixture penta-BDE (24-38\% tetra-BDE, 50-60\% penta-BDE, 4-8\% esa-BDE). In these mixtures, most abundant congeners are constituted by tetra-BDE $2,2^{\prime}, 4,4^{\prime}$ (IUPAC n. 47), pentaBDE 2,2', 4, $4^{\prime}, 5$ (IUPAC n. 99) and penta-BDE 2,2', 4, $4^{\prime}, 6$ (IUPAC n. 100), esa-BDE 2,2', 4, 4', 5, $5^{\prime}$ (IUPAC n. 153) and esa-BDE 2,2',4,4',5,6' (IUPAC n. 154). These mixtures are viscose liquids principally used in industrial fabrication of clothes, foams, resins, polyurethane foam products such as furniture and upholstery in domestic furnishing, and in the automotive and aviation industries. The European Union banned the use of this mixture in August 2004. 
- Mixture octa-BDE (10-12\% esa-BDE, 44\% epta-BDE, 31-35\% octa-BDE, 10-11\% nona-BDE, $<1 \%$ deca-BDE). In these mixtures, most abundant congeners are epta-BDE $2,2^{\prime}, 4,4^{\prime}, 5^{\prime}, 6$ (IUPAC n. 183), and esa-BDE 2,2',4,4',5,5' (IUPAC n. 153). These mixtures are white dusts and are commonly used in little objects for house and office purposes made by plastic products, such as housings for computers, automobile trims, telephone handsets and kitchen appliance casings.

- Mixture deca-BDE (<3\% nona-BDE, $>97 \%$ deca-BDE (IUPAC n. 209). These mixtures are white dusts. In 2003 they represent above the $80 \%$ of the annual production of PBDE and they are, currently, the only PBDE product in production. Deca-BDE are commonly used in the following applications: thermoplastic, elastomeric, and thermo set polymer systems, including high impact polystyrene (HIPS), polybutylene terephthalate (PBT), nylon, polypropylene, low-density polyethene (LDPE), ethylene-propylene-diene rubber and ethylene-propylene terpolymer (EPDM), unsaturated polyester, epoxy. Are used for wire and cable insulation, coatings and adhesive systems, including back-coatings for fabrics, and electronic instruments [36; 38].

PBDEs are semi volatile compounds characterized by a low vapor pressure and a scarce water solubility. These properties tends to decrease with the level of substitutions by bromine atoms in the molecular structure whereas hydrophobic properties increase. Octanol/water distribution coefficients $\left(\mathrm{K}_{\mathrm{ow}}\right)$ are variable with substitutions and are included within: 5.9-6.2 for tetra-BDE, 6.5-7.0 for penta-BDE, 8.4-8.9 for octa-BDE, and 10.0 for deca-BDE. PBDEs half-life in air are extimated to be about two days, while in water longer times are modeled (two months) whereas in soils and sediments average half-lives are six months [40].

\begin{tabular}{lccccccc}
\hline PBDEs & Isomer & $\begin{array}{c}\text { Molecular } \\
\text { formula }\end{array}$ & $\begin{array}{c}\text { Molecular } \\
\text { mass }\end{array}$ & \% bromine & $\begin{array}{c}\text { Vapor } \\
\text { pressure }\end{array}$ & $\begin{array}{c}\text { Octanol/water } \\
\text { distribution } \\
\text { coefficient }\end{array}$ & $\begin{array}{c}\text { Solubility in } \\
\text { water }\end{array}$ \\
\hline $\begin{array}{l}\text { Measure } \\
\text { ment unit }\end{array}$ & - & - & $g / m o l$ & $m / m$ & $25^{\circ} \mathrm{C}, \mathrm{Pa}$ & log Pow & $21^{\circ} \mathrm{C}, \mu \mathrm{g} / \mathrm{L}$ \\
\hline mono-PBDE & 3 & $\mathrm{C}_{12} \mathrm{H}_{9} \mathrm{BrO}$ & 249.0 & 32.09 & & 3.6 & 4000 \\
\hline di-PBDEs & 12 & $\mathrm{C}_{12} \mathrm{H}_{8} \mathrm{Br}_{2} \mathrm{O}$ & 327.9 & 48.74 & 2.0 & 5.1 & 500 \\
\hline tri-PBDE & 24 & $\mathrm{C}_{12} \mathrm{H}_{7} \mathrm{Br}_{3} \mathrm{O}$ & 406.8 & 58.93 & $2.010^{-2}$ & 5.9 & 90 \\
\hline tetra-PBDE & 42 & $\mathrm{C}_{12} \mathrm{H}_{6} \mathrm{Br}_{4} \mathrm{O}$ & 485.7 & 65.81 & $4.010^{-4}$ & 6.3 & 20 \\
\hline penta-PBDE & 46 & $\mathrm{C}_{12} \mathrm{H}_{5} \mathrm{Br}_{5} \mathrm{O}$ & 564.6 & 70.77 & $3.010^{-5}$ & 6.8 & 5 \\
\hline hexa-PBDE & 42 & $\mathrm{C}_{12} \mathrm{H}_{4} \mathrm{Br}_{6} \mathrm{O}$ & 643.5 & 74.51 & $9.010^{-6}$ & 7.3 & 2 \\
\hline hepta-PBDE & 24 & $\mathrm{C}_{12} \mathrm{H}_{3} \mathrm{Br}_{7} \mathrm{O}$ & 722.4 & 77.43 & $5.010^{-6}$ & 7.9 & 0.7 \\
\hline octa-PBDE & 12 & $\mathrm{C}_{12} \mathrm{H}_{2} \mathrm{Br}_{8} \mathrm{O}$ & 801.3 & 79.78 & $4.010^{-6}$ & 8.5 & 0.3 \\
\hline nona-PBDE & 3 & $\mathrm{C}_{12} \mathrm{HBr}_{9} \mathrm{O}$ & 880.1 & 81.71 & $3.010^{-6}$ & 9.0 & 0.16 \\
\hline deca-PBDE & 1 & $\mathrm{C}_{12} \mathrm{Br}_{10} \mathrm{O}$ & 959.0 & 83.32 & $2.610^{-6}$ & 9.5 & 0.10 \\
\hline
\end{tabular}

Table 2. Substance identification and principal molecular properties of PBDEs (polybrominated diphenyl ethers) are summarized. The number of isomers, the molecular formula, molecular mass, \% of bromine, vapor pressure, octanol/ water distribution coefficients, and solubility in water are reported. Data collected by the European Food Safety Authority [41]. 


\section{Sources, distribution dynamics, and environmental levels}

Concerning PFCs, principal environmental sources are represented by the direct diffusion of surfactants, lubricants, paints, polishes, foams propellants, agrochemicals, adhesives, refrigerants, fire retardants, and medicines containing these chemicals. Indirect releases could occurs from food packaging and painted manufacturing when discharged and exposed to rain and bad weather conditions. Nevertheless, the large use of fire-fighting materials containing PFCs both when a critical fire occurs and to prevent accidents in high risk procedure (i.e. military or firemen exercitations, routine activities, airports activities), represents the principal direct diffusion of these chemicals on the ground able to affect wide geographical surfaces, superficial and groundwater [31].

As regard as PBDEs, environmental releases could occurs during manufacturing lifetimes. Releasing mechanism are not completely cleared, however, it is believed that PBDEs are released to the air when objects are manufactured and during object's life span. Their disposal and waste could produce releases too [42]. In the last years recycling of end products containing PBDE is becoming the principal source of release of these chemicals in the environment [43]. Burning of plastics, waste electronic goods, and oil shale may provide an additional PBDEs loads both in atmosphere and soil. Also, productive processes represents an important source, high levels are measured in environmental matrices closed to the flame-retardants factories [40].

Monitoring PFCs and PBDEs in environmental matrices evidenced first of all the needing to develop accurate sampling strategies to collect representative samples from heterogeneous and quickly variable matrices such as air and water are. On the contrary, soils and sediments even if much more stable present structural heterogeneity (i.e. organic matter content and composition, grain-size structure, redox conditions) which could interfere with quantifications and data interpretation. Concerning biota the matter (if it is possible!) is quite more complex. Measured levels could be affected by a lot of different factors as well as age, sex, phase of animal life-stage, lipid content, water content in tissues, part of the animal excised for the analyses and much more other factors. Another point is represented by the sampling treatments and the detecting method adopted to perform laboratory analyses. Different methods are associated to different detection limits, precision and accuracy. Low polluted matrices such as air and water required methods able to detect levels of chemicals at concentrations measured in $\mathrm{pg} / \mathrm{L}$, whereas biological tissues allowed the adoption of quite less sensible methods as well as concentrations are usually measured in $\mathrm{mg} / \mathrm{kg}$ or $\mathrm{ng} / \mathrm{g}$.

Hereby levels reported by the literature in different environmental matrices are reported organizing them per matrix. When possible information about the sampling strategies adopted are reported (i.e. depth of sampling for water and soils or sediments, geographical areas, type of tissues), nevertheless a complete data selection related to the sampling strategies, sampling treatments, and detecting methods has not been possible due to the wide heterogeneity in data acquisition procedures. 
Extremely summarizing, perfluorooctanoic acid (PFOA) is dominant in environmental matrices whereas perfluorooctane sulfonates (PFOS) represents the predominant compound found in biota [44].

\subsection{Air}

Low data are available on air levels, probably due to the great difficult associated to the sampling of this matrix and samples treatment strategies in laboratory. Laboratory (i.e. air, laboratory rooms, instruments, vials, etc.) and cross-over contaminations are extremely simple to occur treating air samples. Furthermore, adopted methods have to be extremely sensitive.

In the period from 1994 to 1995, measured levels of total PBDEs (congeners not specified) reached maximum values of $28 \mathrm{pg} / \mathrm{m}^{3}$ in samples collected in Alert, Canadian Arctic [36]. The rural area of southern Ontario showed in the Early spring of 2000, notably higher levels of total PBDEs (as sum of 21 congeners detailed in the paper) ranging within $10-1,300 \mathrm{pg} / \mathrm{m}^{3}$ [45].

Samples collected in Great Lakes from 1997-1999 evidenced total PBDEs ranging within $5.5-52 \mathrm{pg} / \mathrm{m}^{3}$ [46], comparable levels $\left(3.4-46 \mathrm{pg} / \mathrm{m}^{3}\right)$ were measured in Ontario (2000) by Harner and colleagues [47].

\subsection{Terrestrial environments and soils}

Soil pollution could derived by direct local sources but also by dry-air depositions or runoffs. Humus represents the soil fraction able to accumulate chemicals due to the presence of both hydrophobic and hydrophilic molecules. From here chemicals could be re-volatilized in air, transferred throughout the soil trophic web or be leached throughout rains affecting groundwater ecosystems with possible important consequences for humans. The net dominance of one of these phenomena is a factor dependent to the geographical position of the area (affecting air/soil temperature, sun irradiance, quantities of rains, etc.) and to the soil physico-chemical characteristics.

In soils sampled closed to a polyurethane foam manufacturing facility in the United States, concentrations of total PBDEs (tetra- and penta-BDE) of $76 \mu \mathrm{g} / \mathrm{kg}$ dry weight are reported. Average values measured in soil downwind from the facility were significantly lower 13.6 $\mu \mathrm{g} / \mathrm{kg}$ dry weight [48; 49].

In a study performed throughout the Estonian State, PBDEs levels are defined in soils for the first time. Total values observed ranging within $<0.01-3.2 \mathrm{ng} / \mathrm{g}$ (d.w.) as reported by $\mathrm{Ku}$ mar and colleagues [50]. Even if measured values are not excessive, authors predict a possible increase in the near future due to the particular waste policy of the Estonia.

In Australia, superficial samples collected in 39 remote, agricultural, urban and industrial locations from all states and territories evidenced highest (but not indicated) values from "urban and industrial areas, particularly downstream from sewage treatment plants" (Australian Government, on-line available at: http://www.environment.gov.au/settlements/publications/ 
chemicals/bfr/pubs/factsheet.pdf.). In the same report, levels are indicated to be comparable to values measured in other European and Asian Countries.

\subsection{Aquatic environments}

Aquatic ecosystems represent the final reservoir for PFCs and PBDEs due to their great affinity towards sedimentary and living organic matter. In these systems, measured levels of POPs could increase along the trophic web affecting humans feeding aquatic species.

A recent study performed by Nakata and colleagues [51] evidenced significant differences among tidal and coastal levels of PFOA and PFOS in all considered environmental matrices supporting the existence of different dynamics affecting PFCs distribution and ingress in trophic webs that are zone dependant in marine ecosystems.

Even if some researchers, as reported below, have been performed to evaluate PFCs and PBDEs levels in environmental matrices and biota from river and marine ecosystems, no data are available on environmental levels, bioaccumulation and biomagnification dynamics occurring in coastal lagoons and transitional areas which are completely non explored. This lacking in scientific data could affect risk evaluations linked to human exposure to these chemicals in transitional areas. In fact lagoons and estuaries are the most populated, polluted and productive areas in the world. Feeding exploitation of these not explored ecosystems could represent a notable and not considered risk for humans.

\subsubsection{Water}

A report produced by IFA [52] documented PFOAs levels in drinking and surface fresh water $(n=440)$ ranging within $0.05-456 \mathrm{ng} / \mathrm{L}$. In Europe $(n=119)$ levels recorded are included within 0.33-57.0 ng/L. On the contrary, in the same dataset, measured PFOS levels in drinking and surface fresh water range within 7.1-135 ng/L, while, in Europe values are included within 21.8-56.0 ng/L reporting minimum values notably higher than PFOA levels.

Data acquired on PFOS levels from Six U.S. Urban Centres [53] evidenced ranges within $<0.01-0.063$ (ppb) in drinking water and values included within 0.041-5.29 (ppb) in Municipal wastewater treatment plant effluents (MWTP). Surface water are included within $<0.01-0.138$ (ppb) while "quiet" water values are similar to those observed in MWTP $(<0.01-2.93 \mathrm{ppb})$. These data evidenced that treatment plant effluents could contribute significantly to superficial watercourse pollution.

In 2004, Boulanger and colleagues [54] explored for the first time perfluorooctane surfactants concentrations in sixteen Great Lakes water also determining PFOA and PFOS precursors samples from Great Lakes. Levels measured in water ranged within 27-50 ng/L (PFOA) and 21-70 ng/L (PFOS). The presence of PFOS precursors was recorded in all samples above the LOQ.

Hansenk and colleagues [55] performed a monitoring of the superficial Tennessee River water to evaluate possible contribution to water levels due to the activity of a fluorochemical manufacturing site (settled in Decatur, AL). PFOA levels reported are always below the de- 
tection limit $(25 \mathrm{ng} / \mathrm{L})$ with the exception of samplings collected closed to the fluorochemical plant where PFOA values ranged within 140-598 ng/L. PFOS are recorded at low but often measurable levels $(<25-52 \mathrm{ng} / \mathrm{L})$ in river sampling stations evidencing a significant increase closed to the fluorochemical manufacturing facility $(74.8-144.0 \mathrm{ng} / \mathrm{L})$. This research suggests a strong contribution of plant's outflows to river PFOA and PFOS levels.

In 2005, Yamashita and colleagues [56] developed a reliable and highly sensitive analytical method to monitor PFCs in oceanic water. Between 2002-2004, levels measured in Pacific Ocean ( $n=19)$, South China Sea and Sulu Seas $(n=5)$, north and mid Atlantic Ocean $(n=12)$, and the Japan Sea $(n=20)$ were respectively of: $15-142 \mathrm{pg} / \mathrm{L}, 76-510 \mathrm{pg} / \mathrm{L}, 100-439 \mathrm{pg} / \mathrm{L}$, 137-1,070 pg/L for PFOA and 1.1-78 pg/L, <17-113 pg/L, 8.6-73 pg/L, and 40-75 pg/L for PFOS. Concerning PFOA, samples collected along coastal seawater from several Asian countries (Japan, China, Korea) evidenced levels included within: 1,800-19,200 pg/L (Tokyo Bay), 673-5,450 pg/L (Hong-Kong), 243-15,300 pg/L (China), and 239-11,350 pg/L (Korea). On the contrary, concerning PFOS values in the same sampling sites were: 338-57,700 pg/L (Tokyo Bay), 70-2,600 pg/L (Hong-Kong), 23-9,680 pg/L (China), and 39-2,530 pg/L (Korea).

A research performed in 2007 by Senthilkumar and colleagues [44] evidenced in Japan water PFOA concentrations of 7.9-110 ng/L and PFOS values ranging within $<5.2-10 \mathrm{ng} / \mathrm{L}$.

In 1999, PBDEs levels (mono- to hepta-BDE congeners) concentrations of approximately 6 $\mathrm{pg} / \mathrm{L}$ were measured in Lake Ontario surface waters [57]. In this study, more than $60 \%$ of the total was composed of BDE47 (tetra-BDE) and BDE99 (penta-BDE), with BDE100 (penta$\mathrm{BDE}$ ) and BDEs 153 and 154 (hepta-BDE congeners) each contributing approximately 5\% to $8 \%$ of the total.

Stapleton and Baker [58] analyzed water samples from Lake Michigan in 1997, 1998 and 1999 founding total PBDEs concentrations (BDEs 47, 99, 100, 153, 154 and 183) ranging within 31-158 pg/L.

\subsubsection{Sediment}

In Japan aquatic environments, Senthilkumar and colleagues [44] observed PFOA measurable levels only in sediments sampled from the Kyoto river ranging within 1.3-3.9 ng/g dry weight $(\mathrm{dw})$ and not measurable PFOS levels.

Becker and colleagues [59] evidenced that once released in water, PFCs accumulate into sediments with a PFOA/PFOS ratio of about 10. In particular, PFOA were 10-fold less than PFOS but enrichment observed on sediment was not correlated to the total organic carbon contents.

In 1998, Lake Michigan evidenced average values of total PBDE of $4.2 \mu \mathrm{g} / \mathrm{kg}$ dw [58].

Concerning PBDEs, levels measured in sediments from taken from fourteen Lake Ontario tributary sites [60] evidenced total PBDEs (tri-, tetra, penta-, hexa-, hepta- and deca-BDEs) levels ranging within $12-430 \mu \mathrm{g} / \mathrm{kg}$ dry weight, with tetra- to hexa-BDEs sum ranging within $5-49 \mu \mathrm{g} / \mathrm{kg}$ dry weight. Concentrations of BDE 209 ranged from 6.9 to $400 \mu \mathrm{g} / \mathrm{kg} \mathrm{dw}$ and BDE 47, 99 and 209 were the predominant congeners measured in sediments. 
From several sites sampled along the Columbia River system, in south eastern British Columbia, Rayne and colleagues [61] measured PBDE concentrations (as sum from di- to penta-BDE congeners) included within $2.7-91 \mu \mathrm{g} / \mathrm{kg}$.

Sediments from two Arctic lakes in Nunavut Territory evidenced measurable concentrations from 0.075 to $0.042 \mu \mathrm{g}$ BDE $209 / \mathrm{kg} \mathrm{dw}$. One of the two Arctic lakes sampled was located near an airport and PBDEs inputs from this source could not be excluded [62]. Authors hypothesized a particles-mediated transport to the Canadian Arctic due to its low vapour pressure and high octanol-water partition coefficient.

Sludge sampled from Municipal wastewater treatment plants evidenced total PBDEs (21 mono- to deca-BDE congeners) ranging from 1,414 to 5,545 $\mu \mathrm{g} / \mathrm{kg} \mathrm{dw}$ [63]. A regional sewage treatment plant discharging to the Dan River in Virginia evidenced in 2000 total PBDEs (sum of BDEs 47, 99, 100 and 209) of 3,005 $\mu \mathrm{g} / \mathrm{kg} \mathrm{dw}$ [48].

\subsection{Biota}

POPs could accumulate in species evidencing interspecies differences as well as sex and size-related ones [64]. Recent studies evidenced that POPs concentrations in demersal fishes varies significantly relating to the sex, maturity, and reproduction [65].

Data collected in fishes and fishery products [52] evidence PFOA levels ranging within 0.05-5.00 ng/g wet weight (w.w.) (muscle of whole body) in Europe [66], 0.13-18.70 ng/g w.w. in Asia [67; 68], and 0.70-2.40 ng/g w.w. in North America [69].

Crustaceans levels are quite similar in their edible parts and respectively of $0.80-0.90 \mathrm{ng} / \mathrm{g}$ w.w. [66], 0.13-9.50 ng/g w.w. [51], and 0.10-0.50 ng/g w.w. [70] respectively in Europe, Asia, and North America. Observed levels in edible part of molluscs ranged within 0.95-1.20 ng/g w.w. in species from Europe [66], 0.10-22.90 ng/g w.w. from Asia [67; 68]. Molluscs in North America showed levels closed to the detection limits $(0.10 \mathrm{ng} / \mathrm{g}$ w.w.) as reported by Tomy and colleagues [70].

Concerning PFOS in fish muscles or whole body ranged within 0.60-230 ng/g w.w. in Europe, 0.380-37.30 ng/g in Asia [68], and 15.1-410 ng/g in North America [71]. Crustaceans evidences levels included within 8.30-319 in Europe [66], 0.15-13.9 in Asia [67], and 0.03-0.90 in North America [70], while molluscs showed PFOS levels of 0.80-79.80 in Europe [72], 0.114-47.200 in Asia [68], and 0.080-0.600 in North America.

Kannan and colleagues [73] performed a screening of PFOA and PFOS in wildlife species from different trophic levels and ecosystems. Concerning PFOS in blood samples collected in aquatic mammals and fishes, a tendency to the decrease of measured levels is reported for bottlenose dolphins $>$ bluefish tuna $>$ swordfish. They reported that PFOS concentrations (61 ng/g, w.w.) measured in cormorant livers collected from Sardinia Island (Italy) are lower than PFOA (95 ng/g, w.w.) but significantly correlated.

In the same research, PFOS levels measured in liver samples collected from ringed and gray seals (Bothnian Bay, Baltic Sea) range within 130-1,100 ng/g, w.w.. In this case, no relationships are observed between PFOS levels and ringed or gray seals age but levels measured in 
livers are 2.7-5.5 fold higher than values in blood with a positive strong correlation between blood and liver levels. Concerning white-tailed sea eagles (Germany and Poland) indicate increasing of concentrations from 1979 to 1990s. Livers of Atlantic salmons do not evidenced measurable levels neither PFOS nor PFOA.

In 2007, Senthilkumar and colleagues [44] define levels of PFOA and PFOS in biotic compartment of aquatic ecosystems in Japan. Concerning fish tissues, only jack mackerel showed PFOA and PFOS respectively at averages of 10 and $1.6 \mathrm{ng} / \mathrm{g}$ w.w.. Wildlife livers contained PFOS levels ranging within $0.15-238 \mathrm{ng} / \mathrm{g}$ w.w. and PFOA values included within $<0.07-7.3 \mathrm{ng} / \mathrm{g}$ w.w.. Cormorants showed maximum accumulation followed by eagle, raccoon dog and large-billed crow.

Kannan and colleagues [73] measured PFOA and PFOS levels in livers of birds collected from Japan and Korea $(n=83)$. PFOS was found in the livers of $95 \%$ of the birds analyzed at concentrations greater than the limit of quantitation ( $\mathrm{LOQ}=10 \mathrm{ng} / \mathrm{g}, \mathrm{w} . \mathrm{w}$.). The greatest concentration of PFOS of $650 \mathrm{ng} / \mathrm{g}$, w.w., was found in the liver of a common cormorant from the Sagami River in Kanagawa Prefecture.

Borghesi and colleagues [24] evidenced a PBDEs concentrations in Antarctic fish species ranging within average of $0.09 \mathrm{ng} / \mathrm{g}$ (w.w.) recorded in G. nicholsi to average of $0.44 \mathrm{ng} / \mathrm{g}$ (w.w.) measured in C. gunnari. In Mediterranean tuna PBDEs levels were two or three orders of magnitude higher (15 ng/g w.w.). Furthermore, PBDE congener profiles differ between species; low brominated congeners prevailed in Antarctic species while in tuna tetraand penta-bromodiphenyl ethers are the most abundant groups $(41 \%$ and $44 \%$, respectively). In the same study, a strong correlation with the fish length is observed for the species $C$. hamatus but the same relation is not recorded considering the weight. Tuna evidences a gender dependency in PBDEs concentrations in fact levels are significantly high in females than in males (18 ng/g vs $13 \mathrm{ng} / \mathrm{g}$ w.w.) which authors attribute to the lower fat content in males.

\section{Human exposure}

PBDEs levels in humans have increased over the past several decades. Schiavone and colleagues [74] measured PBDEs in human lipid tissues from Italy even if at values lower than other POPs (PCBs and DDTs). These chemicals are structurally similar to thyroid hormones (i.e. thyroxine T4) and could disrupt thyroid homeostasis as observed in laboratory experiments on animals [75] causing damages similar to thyroid hormone deficiencies [76; 77].

Effects on male reproductive system have been documented by the literature due to the weak estrogenic/antiestrogenic activity of these chemicals [78]. In rats, the exposure to a single dose of $60 \mu \mathrm{g} / \mathrm{kg}$ body weight (b.w.) of PeBDE-99 produces significant decreases of sperm numbers. Akutsu and colleagues [79] evidenced relationship between human serum PBDEs and sperm quality. In particular, PBDE levels in Japan men are comparable to those found in European countries and a strong inverse correlations were ob- 
served between the serum concentration PeBDE-99 and sperm concentration $(r=-0.841$, $\mathrm{p}=0.002)$ and testis size $(\mathrm{r}=-0.764, \mathrm{p}=0.01)$.

The Department of the Environment and Water Resources of Australia founded in 2004 a research aimed to evaluate PBDEs levels in indoor environments collecting and analysing samples from air, dust and surfaces from homes and offices in south-east Queensland. Concentrations of PBDEs were greater in indoor air than in outdoor once, evidencing that major risks are related to the indoor exposure. Furthermore, the lowest PBDE concentration in indoor dust was found in a house with no carpet, no air-conditioning, and which was older than five years. The highest concentration was found in an office with carpet and air-conditioning, and which had been refurbished in the last two years. A recent study developed by Meeker et al. [77] evidenced altered serum hormone levels in US men affected by infertility clinic $(n=24)$ as a result of indoor exposure to PBDE. BDE 47 and 99 were detected in $100 \%$ of dust samples, and BDE 100 was detected in $67 \%$ of dust samples. A significant inverse relationship between dust PBDE concentrations and free androgen index was observed. Furthermore, dust PBDE concentrations were inversely associated with luteinizing hormone $(\mathrm{LH})$ and follicle stimulating hormone (FSH), and positively associated with inhibin $\mathrm{B}$ and sex hormone binding globulin (SHBG).

Concerning POPs levels in humans, infants show the higher feeding exposure compared to adults due to their high feed consumption per kilogram of body weight. Weijs et al., [80] evidenced in not-breastfed Dutch infants a progressively increasing exposure to POPs during the first year growth from the birth due to the diet changes. Concerning PBDEs, the mean level measured in breast milk was $3.93 \pm 1.74 \mathrm{ng} / \mathrm{g}$ lipid and the estimated PBDE daily intake for a breastfed infant was $20.6 \mathrm{ng} / \mathrm{kg}$ b.w./day after delivery [81].

Chao and colleagues [82] evidenced that, in Taiwan, PBDEs levels in breast milk $(n=46)$ are associated with demographic parameters, socioeconomic status, lifestyle factors, and occupational exposure. Average levels measured in 2010 (1.07-3.59 ng/g lipid) were 0.7 -fold lower than in 2000. Furthermore higher levels of PBDEs were positively correlated to the maternal age and are not correlated with maternal pre-pregnant BMI (Body mass index), parity, and lipid contents of breast milk.

PBDEs level in breast milk is lower in more educated women after controlling for age and pre-pregnancy BMI in tested mothers, nevertheless these results are not completely in agreement with Wang and colleagues [83] which evidenced that the mean level of BDE47 in breast milk from mothers with pre-pregnant BMI $<22.0 \mathrm{~kg} / \mathrm{m}^{2}$ had a significantly higher magnitude compared to those with pre-pregnant BMI $>22.0 \mathrm{~kg} / \mathrm{m}^{2}$ (1.59 vs $0.995 \mathrm{ng} / \mathrm{g}$ lipid, $p=0.041$ ) and no relationships between PBDEs exposure levels and women's age, parity, blood pressure, annual household income, and education level.

Evidences regarding a relationship between PBDEs levels in breast milk and seafood consumptions in Taiwan has been explored by the literature [83]. Women eating more fish and meat show not significantly higher PBDE levels than others nevertheless, a significant difference in PBDE levels was demonstrated between the higher (2.15 ng/g lipid) and lower (3.98 $\mathrm{ng} / \mathrm{g}$ lipid) shellfish consuming subjects $(p=0.002)$ after an adjustment for the confounders. 
Concerning ratios (PCB153/BDE47, PCB153/BDE153, PCB153/PBDEs) a significant correlation with frequent consumption of fish and shellfish is observed.

\section{Ecotoxicological effects}

Data collected by $3 \mathrm{M}[84 ; 85]$ on ecotoxicological effects of PFOS on aquatic species evidenced after $96 \mathrm{~h}$ of exposure an $\mathrm{E}_{\mathrm{b}} \mathrm{C}_{50 \text { (biomass) }}$ of $71 \mathrm{mg} / \mathrm{L}$, an $\mathrm{E}_{\mathrm{g}} \mathrm{C}_{50 \text { (growth rate) }}$ of $126 \mathrm{mg} / \mathrm{L}$, and a $\mathrm{NOEC}_{\text {(biomass/growth rate) }}$ of $48 \mathrm{mg} / \mathrm{L}$ on Selenastrum capricornutum (Algae). Acute effects on the oyster shell deposition are observed at $2.1 \mathrm{mg} / \mathrm{L}$ (96h NOEC) whereas subchronic/chronic effects were recorded on Mysidopsis bahia (mysid. shrimp) at $0.25 \mathrm{mg} / \mathrm{L}$ (35-day NOEC reproduction/growth). The same species evidenced respectively acute effects at $4.0 \mathrm{mg} / \mathrm{L}$ (96h $\mathrm{EC}_{50}$ ) and $1.2 \mathrm{mg} / \mathrm{L}$ (96h NOEC).

The species Crassostrea virginica evidenced acute toxicity at levels higher than $3.0 \mathrm{mg} / \mathrm{L}$ (96h $\left.\mathrm{EC}_{50}\right)$ and $96 \mathrm{~h} \mathrm{NOEC}$ at $1.9 \mathrm{mg} / \mathrm{L}$.

Acute toxicity is observed in Daphnia magna exposing animals at $66 \mathrm{mg} / \mathrm{L}\left(48 \mathrm{~h} \mathrm{EC}_{50}\right)$ whereas chronic effects are observed over $7 \mathrm{mg} / \mathrm{L}$ (28day $\mathrm{NOEC}_{\text {reproduction }}$ ).

Unio compalmatus (freshwater mussel) evidenced $96 \mathrm{~h} \mathrm{LC}_{50}$ of $59 \mathrm{mg} / \mathrm{L}$ and $96 \mathrm{~h}$ NOEC of $20 \mathrm{mg} / \mathrm{L}$.

Sanderson and colleagues [86] evidenced the ecological effects induced by the exposure to perfluorinated surfactants (PFOS and PFOA), on zooplankton species performing using classical ecotoxicological tests, 30-L indoor microcosm and 12,000-L outdoor microcosm experiments. The zooplankton community considered in this experiment was composed by the following representative species: Cyclops diaptomus, C. strenuus, Canthocamptus staphylinus, D. magna, Keratella quadrata, Phyllopoda sp., Echninorhynchus sp., Ostracoda sp., and total Rotifera sp. In addition to zooplankton and pond snails, occasional macrophytes (Elodea canadansis and Myriophyllum spicatum), and larger invertebrates (Ephemeroptera sp., Assellus aquaticus) were present.

Results evidenced that zooplankton had lower tolerance toward PFOS than toward PFOA. Researchers observed that "with increasing concentrations the zooplankton community became simplified toward more robust rotifer species, which, as an indirect effect, increased their abundance due to a shift in competition and predation".

Concerning PFOA, classical ecotoxicological tests results on $\mathrm{LOEC}_{\text {community }}$ are not available, whereas 30-L indoor and 12,000-L outdoor produce similar results (LOEC community 30-70 mg/L).

Concerning PFOS, classical ecotoxicological tests evidenced $\mathrm{LOEC}_{\text {community }}$ ranges within $13-50 \mathrm{mg} / \mathrm{L}$, while $30-\mathrm{L}$ indoor and 12,000-L outdoor exposure tests produce a $\mathrm{LOEC}_{\text {community }}$ respectively of $1-10 \mathrm{mg} / \mathrm{L}$ and $10-30 \mathrm{mg} / \mathrm{L}$. 
Concerning fishes the species Pimephales promelas (fathead minnow) shows $96 \mathrm{~h} \mathrm{LC}_{50}$ of 10 $\mathrm{mg} / \mathrm{L}$ and $96 \mathrm{~h}$ NOEC of $3.6 \mathrm{mg} / \mathrm{L}$, the species Lepomis macrochirus (bluegill sunfish) has a $96 \mathrm{~h}$ $\mathrm{LC}_{50}$ of $7.8 \mathrm{mg} / \mathrm{L}$ and $96 \mathrm{~h} \mathrm{NOEC} \mathrm{of} 4.5 \mathrm{mg} / \mathrm{L}$.

Chronic exposure of the fathead minnow Pimephales promelas reported 42-day $\mathrm{NOEC}_{\text {survival }}$ of $0.33 \mathrm{mg} / \mathrm{L}$ and 47 -day early life LOEC of $0.65 \mathrm{mg} / \mathrm{L}$.

Functional studies evidenced that PFOS inhibits gap junction intercellular communication (GJIC) in rat liver epithelial cells cultured in vitro (personal comunication reported in [29]) and that it is an uncoupler of phosphorylation in rat liver mitochondria (personal comunication reported in [29]).

PBDEs can inhibit growth in colonies of plankton and algae and depress the reproduction of zooplankton.

Laboratory mice and rats have also shown liver function disturbances and damage to developing nervous systems as a result of exposure to PBDEs (http://www.environment.gov.au/ settlements/chemicals/bfrs/index.html).

Ecotoxicological tests performed on PBDEs on different species and medium following ex-

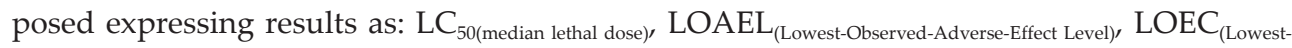

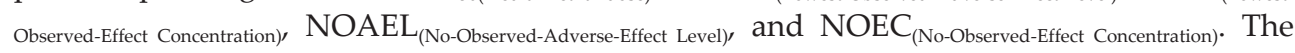
use of the letter "a" following data means that in the study reported highest concentration (or dose) tested did not result in statistically significant results. Since the NOEC or NOAEL could be higher, the NOEC or NOAEL are described as being greater than or equal to the highest concentration (or dose) tested.

As reported by CMABFRIP [87], Daphnia magna (younger than 24h old at the start of the exposure) exposed to a PeBDE mixture containing 33.7\% of tetra-BDE, 54.6\% of penta-BDE, and $11.7 \%$ hexa-BDE following the GLP, protocol based on OECD (Organisation for Economic Co-operation and Development) 202, TSCA (Toxic Substances Control Act) Title 40 and ASTM E1193-87, evidences reported levels:

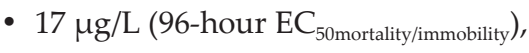

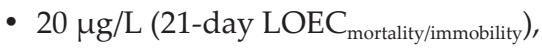

- $9.8 \mu \mathrm{g} / \mathrm{L}$ (21-day $\left.\mathrm{NOEC}_{\text {mortality/immobility }}\right)$,

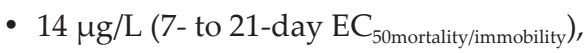

- $14 \mu \mathrm{g} / \mathrm{L}(21-$ day EC E0reproduction $)$,

- $9.8 \mu \mathrm{g} / \mathrm{L}$ (21-day LOEC growth $_{\text {), }}$

- $5.3 \mu \mathrm{g} / \mathrm{L}\left(21-\right.$ day $\left.\mathrm{NOEC}_{\text {growth }}\right)$,

- $9.8 \mu \mathrm{g} / \mathrm{L} \mathrm{LOEC}_{\text {(overall study) }}$

- $5.3 \mu \mathrm{g} / \mathrm{L} \mathrm{NOEC}_{\text {(overall study) }}$.

Exposing Daphnia magna to an OBDE mixture composed by 5.5\% hexa-BDE, $42.3 \%$ heptaBDE, 36.1\% octa-BDE, 13.9\% nona-BDE, 2.1\% deca-BDE (European Communities 2003) for 
21 days with the same protocol adopted for the other exposure (GLP, protocol based on OECD 202, ASTM E1193-87 and TSCA Title 40), results were the follow [13]:

- 21-day $\mathrm{LOEC}_{\text {(survival, reproduction, growth) }}>2.0 \mu \mathrm{g} / \mathrm{L}_{\text {(nominal) }}$ or $1.7 \mu \mathrm{g} / \mathrm{L}_{\text {(measured) }}$

- 21-day $\mathrm{NOEC}_{\text {(survival, reproduction, growth) }}>=2.0 \mu \mathrm{g} / \mathrm{L}_{\text {(nominal) }}$ or $1.7 \mu \mathrm{g} / \mathrm{L}_{\text {(measured) }}{ }^{\mathrm{a}}$

- 21-day $\mathrm{EC}_{50 \text { (survival, reproduction, growth) }}>2.0 \mu \mathrm{g} / \mathrm{L}_{\text {(nominal) }}$ or $1.7 \mu \mathrm{g} / \mathrm{L}_{\text {(measured) }}$

The Great Lakes Chemical Corporation [88], reported ecotoxicological results obtained on adults of the species Lumbriculus variegatus. The exposure mixture of PeBDE is composed by the $0.23 \%$ tri-BDE, $36.02 \%$ of tetra-BDE, $55.10 \%$ penta-BDE, $8.58 \%$ hexa-BDE and the exposure protocol is GLP, protocol based on Phipps et al. [89], ASTM E1706-95b and U.S. EPA OPPTS (Office of Prevention, Pesticides and Toxic Substances) No. 850.1735. Animals were exposed at $23 \pm 2{ }^{\circ} \mathrm{C}$, pH 7.9-8.6, DO 6.0-8.2 mg/L, hardness $130 \mathrm{mg} / \mathrm{L}$ as $\mathrm{CaCO}_{3}$. On artificial sediment with the following characteristics: $\mathrm{pH}$ 6.6, water holding capacity $11 \%$, mean organic matter $<2 \%, 83 \%$ sand, $11 \%$ clay, $6 \%$ silt.

Results collected were the follows:

- 28-day LOEC (survival/reproduction) $=6.3 \mathrm{mg} / \mathrm{kg} \mathrm{dw}$ of sediment

- 28-day $\mathrm{NOEC}_{\text {(survival/reproduction) }}=3.1 \mathrm{mg} / \mathrm{kg} \mathrm{dw}$ of sediment

- 28-day $\mathrm{EC}_{50 \text { (survival/reproduction) }}>50 \mathrm{mg} / \mathrm{kg} \mathrm{dw}$ of sediment

- growth $_{\text {(dry weights) }}$ not significantly different from solvent control and not concentration-dependent.

The exposure of the same species to an OBDE (DE-79) mixture characterized by the $78.6 \%$ bromine content following the GLP, protocol based on Phipps et al. [89], ASTM E1706-95b and U.S. EPA OPPTS 850.1735, evidenced the following results [90; 91]:

- 28-day $\mathrm{LOEC}_{\text {(survival/reproduction, growth) }}>1,340$ (2\% Organic carbon, OC) or 1272 (5\% OC) mg/kg $\mathrm{dw}$ of sediment,

- 28-day $\mathrm{NOEC}_{\text {(survival/reproduction, growth) }}>=1,340(2 \% \mathrm{OC})$ or $1,272(5 \% \mathrm{OC}) \mathrm{mg} / \mathrm{kg} \mathrm{dw}$ of sediment,

- 28-day $\mathrm{EC}_{50 \text { (survival/reproduction, growth) }}>1,340$ (2\% OC) or 1,272 (5\% OC) mg/kg dw of sediment,

- For $2 \%$ OC study: average individual dry weights for treatments statistically lower than in control; not considered treatment-related by authors, as average biomass in treatments comparable to control.

The exposure of the adult earthworm Eisenia fetida to an OBDE (DE-79) mixture at $78.6 \%$ bromine content following the GLP, protocol based on U.S. EPA OPPTS 850.6200, OECD 207 and proposed OECD (2000) guideline on artificial soil (sandy loam, 69\% sand, 18\% silt, 13\% clay, $8.0 \%$ organic matter, $4.7 \%$ carbon) at $17-21^{\circ} \mathrm{C}$ with a photoperiod of $16: 8$ light:dark, $\mathrm{pH}$ 5.9-6.8, soil moisture $22.0-33.5 \%$.

Results [92] obtained are the follow: 
- 28-day $\mathrm{LOEC}_{\text {(mortality) }}>1,470 \mathrm{mg} / \mathrm{kg}$ dry soil

- 28-day $\mathrm{NOEC}_{(\text {mortality) }}>=1,470 \mathrm{mg} / \mathrm{kg}$ dry soil ${ }^{\mathrm{a}}$

- 28-day $\mathrm{EC}_{10}, \mathrm{EC}_{50 \text { (survival) }}>1,470 \mathrm{mg} / \mathrm{kg}$ dry soil

- 56-day $\mathrm{LOEC}_{(\text {reproduction) }}>1,470 \mathrm{mg} / \mathrm{kg}$ dry soil

- 56-day $\mathrm{NOEC}_{(\text {(reproduction) }}>=1,470 \mathrm{mg} / \mathrm{kg}$ dry soila

- 56-day $\mathrm{EC}_{10}, \mathrm{EC}_{50 \text { (reproduction) }}>1,470 \mathrm{mg} / \mathrm{kg}$ dry soil

ACCBFRIP [93] reported for the exposure of the species Eisenia fetida to a DBDE mixture composed by the $97.90 \%$ of deca-BDE, the following results:

- 28-day $\operatorname{LOEC}_{\text {(survival) }}>4,910 \mathrm{mg} / \mathrm{kg}$ dry $\operatorname{soil}_{\text {(mean measured) }}$

- 28-day $\mathrm{NOEC}_{\text {(survival) }}>=4,910 \mathrm{mg} / \mathrm{kg}$ dry soil (mean measured)a

- 28-day $\mathrm{EC}_{10}, \mathrm{EC}_{50 \text { (survival) }}>4,910 \mathrm{mg} / \mathrm{kg}$ dry soil (mean measured)

- 56-day $\mathrm{LOEC}_{\text {(reproduction) }}>4,910 \mathrm{mg} / \mathrm{kg}$ dry soil (mean measured)

- 56-day $\mathrm{NOEC}_{\text {(reproduction) }}>=4,910 \mathrm{mg} / \mathrm{kg}$ dry soil (mean measured)a

- 56-day $\mathrm{EC}_{10}, \mathrm{EC}_{50 \text { (reproduction) }}>4,910 \mathrm{mg} / \mathrm{kg}$ dry soil (mean measured)

On the contrary, the exposure of Lumbriculus variegatus to a DBDE mixture composed by $97.3 \%$ of deca-BDE and $2.7 \%$ of other (not specified) composite from three manufacturers), evidenced the following results [94; 95]:

- 28 -day $\mathrm{NOEC}_{\text {(survival/reproduction, growth) }}>=4,536(2.4 \%$ OC) or $3,841(5.9 \%$ OC) $\mathrm{mg} / \mathrm{kg} \mathrm{dw}$ of sediment,

- 28 -day $\mathrm{LOEC}_{\text {(survival/reproduction, growth) }}>4,536(2.4 \%$ OC) or 3,841 $(5.9 \%$ OC) $\mathrm{mg} / \mathrm{kg} \mathrm{dw}$ of sediment,

- 28-day $\mathrm{EC}_{50 \text { (survival/reproduction, growth) }}>4,536(2.4 \%$ OC) or $3,841(5.9 \%$ OC) $\mathrm{mg} / \mathrm{kg} \mathrm{dw}$ of sediment.

The Great Lakes Chemical Corporation [96], reported ecotoxicological results obtained on the species Zea mays corn. The exposure mixture was the same adopted on the earthworm [97] and the exposure protocol is GLP, protocol based on U.S. EPA OPPTS Nos. 850.4100 and 850.4225 and OECD 208 (based on 1998 proposed revision). Plants were exposed on artificial soil (92\% sand, $8 \%$ clay and $0 \%$ silt), with $\mathrm{pH} 7.5$, organic matter content $2.9 \%$ and watering with well water using subirrigation (14:10 light:dark photoperiod, $16.0-39.9^{\circ} \mathrm{C}$, relative humidity $19-85 \%)$.

Results collected were the follows:

- no apparent treatment-related effects on seedling emergence,

- 21-day $\mathrm{LC}_{25}, \mathrm{LC}_{50 \text { (seedling emergence) }}>1,000 \mathrm{mg} / \mathrm{kg}$ soil dw, 
- mean shoot height significantly reduced at 250,500 and ,1000 mg/kg soil dw relative to controls,

- 21-day $\mathrm{EC}_{25}, \mathrm{EC}_{50 \text { (mean shoot height) }}>1,000 \mathrm{mg} / \mathrm{kg}$ soil dw,

- mean shoot weight significantly reduced at $62.5,125,250,500$ and 1,000 mg/kg soil dw relative to controls,

- 21-day $\mathrm{EC}_{25 \text { (mean shoot weight) }}=154 \mathrm{mg} / \mathrm{kg}$ soil dw,

- 21-day $\mathrm{EC}_{50 \text { (mean shoot weight) }}>1,000 \mathrm{mg} / \mathrm{kg}$ soil dw,

- 21-day LOEC $_{\text {(mean shoot weight) }}=62.5 \mathrm{mg} / \mathrm{kg}$ soil dw

- 21-day $\mathrm{EC}_{05}$ and (estimated) $\mathrm{NOEC}_{\text {(mean shoot weight) }}=16.0 \mathrm{mg} / \mathrm{kg}$ soil dw.

The Great Lakes Chemical Corporation [98], reported ecotoxicological results obtained on the Rat. The exposure mixture PeBDE (DE-71) was composed by $45-58.1 \%$ of penta-BDE, 24.6-35\% tetra-BDE [99; 100]. Exposure doses of PeBDE were 0, 2, 10 and $100 \mathrm{mg} / \mathrm{kg}$ bw per day (doses adjusted weekly based on mean body weight of animals) and after 90 days observed effects were:

- decreased food consumption and body weight, increased cholesterol, increased liver and urine porphyrins at $100 \mathrm{mg} / \mathrm{kg}$ bw dose,

- increased absolute and relative liver weights at 10 and $100 \mathrm{mg} / \mathrm{kg} \mathrm{bw}$, with return to normal ranges after 24-week recovery period,

- compound-related microscopic changes to thyroid and liver at all dosage levels,

- microscopic thyroid changes reversible after 24 weeks,

- microscopic liver changes still evident at all dosage levels after 24-week recovery period,

- liver cell degeneration and necrosis evident in females at all dosage levels after 24-week recovery,

- LOAEL (liver cell damage) $=2 \mathrm{mg} / \mathrm{kg}$ bw,

- NOAEL could not be determined, as a significant effect was observed at the lowest dose tested.

Exposing rats to a DBDE (Dow-FR-300-BA) mixture with the relative composition of $77.4 \%$ of deca-BDE, $21.8 \%$ nona-BDE and $0.8 \%$ octa-BDE, results evidenced [101]:

- LOAEL (enlarged liver, thyroid hyperplasia) $=80 \mathrm{mg} / \mathrm{kg}$ bw per day,

- $\mathrm{NOAEL}=8 \mathrm{mg} / \mathrm{kg}$ bw per day.

Little data have been gathered on the associations between PBDEs exposure and birth outcome and female menstruation characteristics in both epidemiological and animal studies. In rats, the in utero exposure to PBDEs reduces the number of ovarian follicles in rat females and causes permanent effects on rat males [81]. 
Breslin and colleagues [102] exposed rabbits to an OBDE (Saytex 111) mixture $0.2 \%$ pentaBDE, $8.6 \%$ hexa-BDE, $45.0 \%$ hepta-BDE, $33.5 \%$ octa-BDE, $11.2 \%$ nona-BDE, $1.4 \%$ deca-BDE evidencing the following results:

- no evidence of teratogenicity,

- $\mathrm{LOAEL}_{\text {(maternal, increased liver weight, decreased body weight gain) }}=15 \mathrm{mg} / \mathrm{kg}$ bw per day,

- $\operatorname{NOAEL}_{\text {(maternal) }}=5.0 \mathrm{mg} / \mathrm{kg}$ bw per day,

- $\mathrm{LOAEL}_{\text {(fetal, delayed ossification of sternebrae) }}=15 \mathrm{mg} / \mathrm{kg}$ bw per day,

- $\operatorname{NOAEL}_{(\text {fetal })}=5.0 \mathrm{mg} / \mathrm{kg}$ bw per day.

\section{Conclusions}

Recent data collected on these chemicals evidence significant levels in environments, wildlife and humans. In particular, observed ecotoxicological effects on species, measured values in humans tissues and their relationships with fertility suggest that PFCs and PBDEs represent an important problem to be quickly solved. Unfortunately, collected data both on chemical distribution in abiotic and biotic matrices are fragmentary and incomplete as well as ecotoxicological studies on laboratory species and microcosms. Studies in aquatic ecosystems and, in particular, in transitional ones have to be improved to allow a correct evaluation of the exposure risk for humans to these compounds due to the dietary intakes.

\section{Author details}

Monia Renzi*

Address all correspondence to: renzi2@unisi.it

Department of Environmental Science, Via Mattioli, University of Siena, Italy

\section{References}

[1] Carson R. [1st. Pub. Houghton Mifflin, 1962]. Silent Spring. Mariner Books. 2002. ISBN 0-618-24906-0.

[2] de Azevedo e Silva CE, Azeredo A, Lailson-Brito J, Machado-Torres JP, Malm O. Polychlorinated biphenyls and DDT in swordfish (Xiphias gladius) and blue shark (Prionace glauca) from Brazilian coast. Chemosphere 2007;67: S48-S53. 
[3] Focardi S, Bargagli R, Corsolini S. Isomer-specific analysis and toxic potential evaluation of polychlorinated biphenyls in Antarctic fish, seabirds and Weddell seals from Terra Nova Bay (Ross Sea). Antarctic Science 1995;7: 31-35.

[4] Bouloubassi I, Mejanelle L, Pete R, Fillaux J, Lorre A, Point V. PAH transport by sinking particles in the open Mediterranean Sea: A 1 year sediment trap study. Marine Pollution Bulletin 2006;52: 560-571.

[5] Corsolini S, Focardi S, Kannan K, Tanabe S, Borrell A, Tatsukawa R. Congener profile and toxicity assessment of polychlorinated biphenyls in dolphins, sharks and tuna collected from Italian coastal waters. Marine Environmental Research 1995;40: 33-53.

[6] Corsolini S, Kannan K, Imagawa T, Focardi S, Giesy JP. Polychloronaphthalenes and other dioxin-like compounds in arctic and antarctic marine food webs. Environmental Science and Technology 2002;36: 3490-3496.

[7] Storelli MM, Marcotrigiano GO. Occurrence and accumulation of organochlorine contaminants in swordfish from Mediterranean Sea: A case study. Chemosphere 2006;62: 375-380.

[8] Storelli MM, Casalino E, Barone G, Marcotrigiano GO. Persistent organic pollutants (PCBs and DDTs) in small size specimens of bluefin tuna (Thunnus thynnus) from the Mediterranean Sea (Ionian Sea). Environment International 2008;34: 509-513.

[9] Liem AKD. Dioxins and dioxin-like PCBs in foodstuffs. Levels and trends. Organohalogen Compounds 1999;44: 1-4.

[10] Sweetman J., Alcock R.E., Wittisiepe J., Jones K.C. 2000. Human exposure to PCDD/Fs in the UK: The development of a modeling approach to give historical and future perspectives. Environ. Int. 26: 37-47.

[11] Falandysz J, Wyrzykowskay B, Puzyny T, Strandbergy L, Rappe C. Polychlorinated biphenyls (PCBs) and their congener specific accumulation in edible fish from the Gulf of Gdansk, Baltic Sea. Food Additives and Contamination 2002;19: 779-795.

[12] Brambilla G, Cherubini G, de Filippis S, Magliuolo M, Di Domenico A. Review of aspects pertaining to food contamination by polychlorinated dibenzodioxins, dibenzofurans, and biphenyls at the farm level. Anal. Chim. Acta 2004;514(1): 1-7.

[13] CMABFRIP (Chemical Manufacturers Association Brominated Flame Retardant Industry Panel). 1997. Octabromodiphenyl oxide (OBDPO): A flow-through life-cycle toxicity test with the cladoceran (Daphnia magna). Final report. Project No. 439A-104, Wildlife International, Ltd., May.

[14] Bommanna GL, Kannan K. Global Organochiorine Contamination Trends: An Overview. Ambio 1994;23(3): 187-191.

[15] UNECE 1998. The 1998 Aarhus Protocol on Heavy Metals. On-line available at: http://www.unece.org/env/lrtap/hm_h1.html. 
[16] Hargrave B, Vass W, Erickson P, Fowler B. Atmospheric transport of organochlorines to the arctic ocean. Tellus 1988;40(B): 480-493.

[17] Fernandez P, Grimalt JO. On the global Distribution of Persistent Organic Pollutants. Chimia 2003;57: 514-521.

[18] Richardson SD, Ternes TA. Water analysis: emerging contaminants and current issues. Analytical Chemistry 2005;77: 3807-3838.

[19] Van de Vijver KI, Hoff P, Das K, Brasseur S, Dongen WV, Esmans E, Reijnders P, Blust R, Coen WD. Tissue Distribution of Perfluorinated Chemicals in Harbor Seals (Phoca vitulina) from the Dutch Wadden Sea. Environmental Science and Technology 2005;39(18): 6978-6984.

[20] Yeung LWY, So MK, Jiang G, Taniyasu S, Yamashita N, Song M, Wu Y, Li J, Giesy JP, Guruge KS, Lam PKS. Perfluorooctanesulfonate and related fluorochemicals in human blood samples from China. Environmental Science and Technology 2006;40(3): 715-720.

[21] Midasch O, Schettgen T, Angerer J. Pilot study on the perfluorooctanesulfonate and perfluorooctanoate exposure of the German general population. International Journal of hygiene and environmental health 2006;209(6): 489-496.

[22] Simcik MF. Air monitoring of persistent organic pollutants in the Great Lakes: IADN vs. AEOLOS. Environmental Monitoring and Assessment 2005;100(1-3): 201-216.

[23] Prevedouros K, Cousins IT, Buck RC, Korzeniowski SH. Sources, fate and transport of perfluorocarboxylates. Environmental Science and Technology 2006;40: 32-44.

[24] Borghesi N, Corsolini S, Leonards P, Brandsma S, de Boer J, Focardi S. Polybrominated diphenyl ether contamination levels in fish from the Antarctic and the Mediterranean Sea. Chemosphere 2009;77: 693-698.

[25] Kannan K, Corsolini S, Falandysz J, Oehme G, Focardi S, Giesy J. Perfluorooctanesulfonate and related fluorinated hydrocarbons in Marine mammals, Fishes, and Birds from Coasts of the Baltic and the Mediterranean Seas. Environmental Science and Technology 2002;36: 3210-3216.

[26] Key BD, Howell RD, Criddle CS. Fluorinated organics in the biosphere. Environmental Science and Technology 1997;31: 2445-2454.

[27] Renner R. Growing concern over perfluorinated chemicals. Environmental Science and Technology 2001;35: 154A-160A.

[28] Butenhoff JL, Gaylor DW, Moore JA, Olsen GW, Rodricks J, Mandel JH, Zobel LR. Characterization of risk for general population exposure to perfluorooctanoate. Regulatory Toxicology and Pharmacology 2004;39: 363-380.

[29] Key BD, Howell RD, Criddle C. Defluorination of Organofluorine Sulfur Compounds by Pseudomonas Sp. Strain D2. Environmental Science and Technology 1998;32: 2283-2287. 
[30] MSDS. Material Safety Data Sheet for FC-203FC Light Water Brand Aqueous Film Forming Foam, 3M Co. 1999. London, ON, Canada.

[31] Moody CA, Field JA. Perfluorinated surfactants and the environmental implications of their use in fire-fighting foams. Environmental Science and Technology 2000;34: 3864-3870.

[32] Moody CA, Martin JW, Kwan WC, Muir DG, Mabury SA. Monitoring Perfluorinated Surfactants in biota and surface water samples following an accidental release of firefighting foam into Etobicoke Creek. Environmental Science and Technology 2002;36: 545-551.

[33] Brooke D, Footitt A, Nwaogu TA. Environmental risk evaluation report: Perfluorooctanesulphonate (PFOS). 2004. On-line available at URL: http://www.environmentagency.gov.uk/commondata/105385/pfos_rer_sept04_864557.pdf./

[34] Kodavanti PRS, Senthil Kumar K, Loganathan BG. Organohalogen pollutants in the environment and their effects on wildlife and human health. International Encyclopedia of Public Health 2008;4: 686.693.

[35] de Boer J, de Boer K, Boon JP. Polybrominated biphenyls and diphenylethers. In: Paasivirta J. (Ed.), The Handbook of Environmental Chemistry. 2000; 61-95. Springer, Berlin.

[36] Alaee M, Arias P, Sjodin A, Bergman A. An overwiew of commercially used brominated flame retardants, their applications, their use patterns in differents countries/ regions and possible modes of release. Enviromental International 2003;9: 683-689.

[37] BSEF. Bromine Science and Environmental Forum. 2000. On-line available at: http:// www.bsef.com/

[38] Birnbaum LS, Staskal DF. Brominated flame retardants: cause for concern?. Environmental Health Perspectives 2004;112: 9-17.

[39] Palm A, Cousins IT, Mackay D, Tysklind M, Metcalfe C, Alaee M. Assessing the environmental fate of chemicals of emerging concern: a case study of the polybrominated diphenyl ethers. Environmental Pollution 2002;117(2): 195-213.

[40] Martellini T. 2008. Studio del trasporto a lungo raggio (LRT) e del destino ambientale di composti organici persistenti (POPs). Scuola di Dottorato in Scienze Dottorato in Scienze Chimiche XXI Ciclo. Università degli Studi di Firenze. Doctoral dissertation, pp. 206.

[41] EFSA 2011. European Food Safety Authority. Scientific Opinion on Polybrominated Diphenyl Ethers (PBDEs) in Food EFSA Panel on Contaminants in the Food Chain (CONTAM). EFSA Journal. 9(5):2156.

[42] Wang Y, Jiang G, Lam PKS, Li A. Polybrominated diphenyl ether in the East Asian environment: A critical review. Environment International 2007;33(7): 963-973. 
[43] Sajwan KS, Kumar KS, Kelley S, Loganathan BG. Deposition of Organochlorine Pesticides, PCBs (Aroclor 1268), and PBDEs in Selected Plant Species from a Superfund Site at Brunswick, Georgia, USA. Bulletin of Environmental Contamination and Toxicology 2009;82(4): 444-449.

[44] Senthilkumar K, Ohi E, Sajwan K, Takasuga T, Kannan K. Perfluorinated Compounds in River Water, River Sediment, Market Fish, and Wildlife Samples from Japan. Bulletin of Environmental Contamination and Toxicology 2007;79: 427-431.

[45] Gouin T, Thomas GO, Cousins I, Barber J, Mackay D, Jones KC. Air-surface exchange of polybrominated diphenyl ethers and polychlorinated biphenyls. Environmental Science and Technology 2002;36(7): 1426-1434.

[46] Strandberg B, Dodder NG, Basu I, Hites RA. Concentrations and spatial variations of polybrominated diphenyl ethers and other organohalogen compounds in Great Lakes air. Environmental Science and Technology 2001; 35: 1078-1083.

[47] Harner T, Ikonomou M, Shoeib M, Stern G, Diamond M. Passive air sampling results for polybrominated diphenyl ethers along an urban-rural transect. 2002. $4^{\text {th }}$ Annual Workshop on Brominated Flame Retardants in the Environment, June 17-18, Canada Centre for Inland Waters, Burlington, Ontario. pp. 51-54.

[48] Hale RC, La Guardia MJ, Harvey E, Mainor TM. Potential role of fire retardant-treated polyurethane foam as a source of brominated diphenyl ethers to the U.S. environment. Chemosphere 2002;46: 729-735.

[49] Hale RC, Alaee M, Manchester-Neesvig JB, Stapleton HM, Ikonomou MG. Polybrominated diphenyl ether (PBDE) flame retardants in the North American environment. Environment International 2003;29: 771-779.

[50] Kumar KS, Priya M, Sajwan KS, Kõlli R, Roots O. Residues of persistent organic pollutants in Estonian soils (1964-2006) Estonian Journal of Earth Sciences 2009;58(2): 109-123.

[51] Nakata H, Kannan K, Nasu T, Cho HS, Sinclair E, Takemura A. Perfluorinated Contaminants in Sediments and Aquatic Organisms Collected from Shallow Water and Tidal Flat Areas of the Ariake Sea, Japan: Environmental Fate of Perfluorooctane Sulfonate in Aquatic Ecosystems. Environmental Science and Technology 2006;40(16): 4916-4921.

[52] IFA. Institute for Occupational Safety and Health of the German Social Accident Insurance. 2001. Subdivision "Information on Hazardous Substances". Alte Heerstr. 111 D-53757 Sankt Augustin, Germany. Available on-line at: http://gestis-en.itrust.de/nxt/ gateway.dll/gestis_en/036110.xml?f=templates $\$ \mathrm{fn}=$ default.htm $\$ 3.0$

[53] OECD, Draft assessment of perfluorooctane sulfonate and its salts. ENV/JM/EXCH, 8. 2002. Paris, France. 
[54] Boulanger B, Vargo J, Schnoor J, Hornbuckle K. Detection of Perfluorooctane Surfactants in Great Lakes Water. Environmental Science and Technology 2004;38: 4064-4070.

[55] Hansenk J, Johnson HO, Eldrige JS, Butenhoff JL, Dick LA. Quantitative Characterization of trace levels of PFOS and PFOA in the Tennessee River. Environmental Science and Technology 2002;36: 1681-1685.

[56] Yamashita N, Kannan K, Taniyasu S, Horii Y, Petrick G, Gamo T. A global survey of perfluorinated acids in oceans. Marine Pollution Bulletin 2005;doi:10.1016/j.marpolbul.2005.04.026.

[57] Luckey FJ, Fowler B, Litten S. Establishing baseline levels of polybrominated diphenyl ethers in Lake Ontario surface waters. Unpublished manuscript dated 2002/03/01. New York State Department of Environmental Conservation, Division of Water, 50 Wolf Road, Albany, NY 12233-3508.

[58] Stapleton HM, Baker JE. Comparing the temporal trends, partitioning and biomagnification of PBDEs and PCBs in Lake Michigan. Abstract. 2001. $3^{\text {rd }}$ Annual Workshop on Brominated Flame Retardants in the Environment, August 23-24, 2001, Canada Centre for Inland Waters, Burlington, Ontario.

[59] Becker AM, Gerstmann S, Frank H. Perfluorooctanoic acid and perfluorooctane sulfonate in the sediment of the Roter Main river, Bayreuth, Germany, Environmental Pollution 2008;doi:10.1016/j.envpol.2008.05.024.

[60] Kolic TM, MacPherson KA, Reiner EJ, Ho T, Kleywegt S, Dove A, Marvin C. Brominated diphenyl ether levels: a comparison of tributary sediments versus biosolid material. Organohalogen Compounds 2004;66: 3830-3835.

[61] Rayne S, Ikonomou MG, Antcliffe B. Rapidly increasing polybrominated diphenyl ether concentrations in the Columbia River system from 1992 to 2000. Environmental Science and Technology 2003;37(13): 2847-2854.

[62] Muir D, Teixeira C, Chigak M, Yang F, D'Sa I, Cannon C, Pacepavicius G, Alaee M. Current deposition and historical profiles of decabromodiphenyl ether in sediment cores. Dioxin 2003, $23^{\text {rd }}$ International Symposium on Halogenated Environmental Organic Pollutants and POPs. Organohalogen Compd. 61: 77-80.

[63] Kolic TM, MacPherson KA, Reiner EJ, Ho T, Kleywegt S, Payne M, Alaee M. Investigation of brominated diphenyl ethers in various land applied materials. 2003. Abstract. $5^{\text {th }}$ Annual Workshop on Brominated Flame Retardants in the Environment, August 22-23, 2003. Boston, MA.

[64] Solé M, Hambach B, Cortijo V, Huertas D, Fernandez P, Company JB. Muscular and Hepatic Pollution Biomarkers in the Fishes Phycis blennoides and Micromesistius poutassou and the Crustacean Aristeus antennatus in the Blanes Submarine Canyon (NW Mediterranean). Archives Environmental Contamination and Toxicology 2009;57: 123-132. 
[65] Bodiguel X, Loizeau V, Le Guellec AM, Roupsard F, Philippon X, Mellon-Duval C. Influence of sex, maturity and reproduction on PCB and p, $\mathrm{p}^{\prime} \mathrm{DDE}$ concentrations and repartitions in the European hake (Merluccius merluccius, L.) from the Gulf of Lions (N.W. Mediterranean). Science of the Total Environment 2009;408: 304-311.

[66] van Leeuwen SPJ, Karrman A, van Bavel B, de Boer J, Lindström G. Struggle for quality in determination of perfluorinated contaminants in environmental and human samples. Environmental Science and Technology 2006;doi: 10.1021/es061052c.

[67] Gulkowska A, Jiang Q, Ka M, Sachi S, Taniyasu, Lam PKS, Yamashita N. Persistent Perfluorinated acids in seafood collected from two cities of China. Environmental Science and Technology 2006;40(12): 3736-3741.

[68] Tseng CL, Liu LL, Chen CM, Ding WH. Analysis of perfluorooctanesulfonate and related fluorochemicals in water and biological tissue samples by liquid chromatography-ion trap mass spectrometry. Journal of Chromatography A 2006;1105(1-2): 119126.

[69] Furdui VI, Stock N, Whittle DM, Crozier P, Reiner E, Muir DCG, Mabury SA. Perfluoroalkyl contaminants in lake trout from the Great Lakes. ENV024 Furdui. "Fluoros" $9^{\text {th }}$ International Symposium on Fluorinated Alkyl Organics in the Environment, August 2005, Toronto, Canada.

[70] Tomy GT, Budakowski WR, Halldorson T, Helm PA, Stern GA, Friesen K. Fluorinated organic compounds in an eastern arctic marine food web. Environmental Science and Technology 2004;38: 6475-6481.

[71] Martin JW, Smithwick MM, Braune BM, Hoekstra PF, Muir DCG, Mabury SA. Identification of Long-Chain Perfluorinated Acids in Biota from the Canadian Arctic. Environmental Science and Technology 2004;38(2): 373-380.

[72] Cunha I, Hoff P, Van de Vijver K, Guilhermino L, Esmans E, De Coen W. Baseline study of perfluorooctane sulfonate occurrence in mussels, Mytilus galloprovincialis, from north-central Portuguese estuaries. Marine Pollution Bulletin 2005;50(10): 1128-1132.

[73] Kannan K, Choi J-W, Iseki N, Senthilkumar K, Kim D, Masunaga S, Giesy JP. Concentrations of perfluorinated acids in livers of birds from Japan and Korea. Chemosphere 2002;49: 225-231.

[74] Schiavone A, Kannan K, Horii Y, Focardi S, Corsolini S. Polybrominated diphenyl ethers, polychlorinated naphthalenes and polycyclic musks in human fat from Italy: Comparison to polychlorinated biphenyls and organochlorine pesticides. Environmental Pollution 2010;158: 599-606.

[75] Zhou T, Taylor MM, DeVito MJ, Crofton KM. Developmental exposure to brominated diphenyl ethers results in thyroid hormone disruption. Toxicological Science 2002;66: 105-116. 
[76] Viberg H, Fredriksson A, Eriksson P. Investigations of strain and/or gender differences in developmental neurotoxic effects of polybrominated diphenyl ethers in mice. Toxicological Science 2004;81: 344-353.

[77] Meeker JD, Johnson PI, Camann D, Hauser R. Polybrominated diphenyl ether (PBDE) concentrations in house dust are related to hormone levels in men. Science of the Total Environment 2009;407: 3425-3429.

[78] Meerts IA, Letcher RJ, Hoving S, Marsh G, Bergman A, Lemmen JG, van der Burg B, Brouwer A. In vitro estrogenicity of polybrominated diphenyl ethers, hydroxylated PBDEs, and polybrominated bisphenol A compounds. Environ Health Perspect 2001;109: 399-407.

[79] Akutsu K, Takatori S, Nozawa S, Yoshiike M, Nakazawa H, Hayakawa K, Makino T, Iwamoto T. Polybrominated Diphenyl Ethers in Human Serum and Sperm Quality. Bulletin of Environmental Contaminant and Toxicology 2008;80: 345-350.

[80] Weijs PJM, Bakker MI, Korver KR, van Goor Ghanaviztchi K, van Wijnen JH. Dioxin and dioxin-like PCB exposure of non-breastfed Dutch infants. Chemosphere 2006;64(9): 1521-1525.

[81] Chao HR, Wang SL, Lee WJ, Wang YF, Päpke O. Levels of polybrominated diphenyl ethers (PBDEs) in breast milk from central Taiwan and their relation to infant birth outcome and maternal menstruation effects. Environment International 2007;33: 239245.

[82] Chao HA, Chen SCC, Chang CM, Koh TW, Chang-Chien GP, Ouyang E, Lin SL, Shy CG, Chen FA, Chao HR. Concentrations of polybrominated diphenyl ethers in breast milk correlated to maternal age, education level, and occupational exposure. Journal of Hazardous Materials 2010;175: 492-500.

[83] Wang YF, Wang SL, Chen FA, Chao HA, Tsou TC, Shy CG, Papke O, Kuo YM, Chao HR. Associations of polybrominated diphenyl ethers (PBDEs) in breast milk and dietary habits and demographic factors in Taiwan. Food and Chemical Toxicology 2008;46: 1925-1932.

[84] 3M 2000. Sulfonated perfluorochemicals in the environment: sources, dispersion, fate and effects. Docket submitted to the US EPA, Washington, DC.

[85] 3M 2003. Health and environmental assessment of perfluorooctane sulfonic acid and its salts. US EPA docket No. AR-226-1486. US Environmental Protection Agency, Washington, DC.

[86] Sanderson H, Boudreau TM, Mabury SA, Solomon KR. Effects of perfluorooctane sulfonate and perfluorooctanoic acid on the zooplanktonic community. Ecotoxicology and Environmental Safety 2004;58: 68-76.

[87] CMABFRIP (Chemical Manufacturers Association Brominated Flame Retardant Industry Panel). 1998. Pentabromodiphenyl oxide (PeBDPO): A flow-through life-cycle 
toxicity test with the cladoceran (Daphnia magna). Project No. 439A-109, Wildlife International, Ltd., September.

[88] Great Lakes Chemical Corporation. 2000. Pentabromodiphenyl oxide (PeBDPO): A prolonged sediment toxicity test with Lumbriculus variegatus using spiked sediment. Project No. 298A-109, Wildlife International, Ltd., April.

[89] Phipps GL, Ankley GT, Benoit DA, Mattson VR. Use of the aquatic oligochaete Lumbriculus variegatus for assessing the toxicity and bioaccumulation of sediment-associated contaminants. Environmental Toxicology and Chemistry 1993;12: 269-279.

[90] Great Lakes Chemical Corporation. 2001. Octabromodiphenyl ether: A prolonged sediment toxicity test with Lumbriculus variegatus using spiked sediment with $2 \%$ total organic carbon. Final report. Project No. 298A-112, Wildlife International, Ltd., February.

[91] Great Lakes Chemical Corporation. 2001. Octabromodiphenyl ether: A prolonged sediment toxicity test with Lumbriculus variegatus using spiked sediment with $5 \%$ total organic carbon. Final report. Project No. 298A-113, Wildlife International, Ltd., February.

[92] Great Lakes Chemical Corporation. 2001. Effect of octabromodiphenyl oxide on the survival and reproduction of the earthworm, Eisenia fetida. Study No. 46419, ABC Laboratories, Inc., December.

[93] ACCBFRIP (American Chemistry Council Brominated Flame Retardant Industry Panel). 2001. Effect of decabromodiphenyl oxide (DBDPO) on the survival and reproduction of the earthworm, Eisenia fetida. Final report. Study No. 465440, ABC Laboratories, Inc., December.

[94] ACCBFRIP (American Chemistry Council Brominated Flame Retardant Industry Panel). 2001. Decabromodiphenyl ether: A prolonged sediment toxicity test with Lumbriculus variegatus using spiked sediment with $2 \%$ total organic carbon. Final report. Project No. 439A-113, Wildlife International, Ltd., February.

[95] ACCBFRIP (American Chemistry Council Brominated Flame Retardant Industry Panel). 2001. Decabromodiphenyl ether: A prolonged sediment toxicity test with Lumbriculus variegatus using spiked sediment with $5 \%$ total organic carbon. Final report. Project No. 439A-114, Wildlife International, Ltd., February.

[96] Great Lakes Chemical Corporation. 2000. Pentabromodiphenyl oxide (PeBDPO): A toxicity test to determine the effects of the test substance on seedling emergence of six species of plants. Final report. Project No. 298-102, Wildlife International, Ltd., April.

[97] Great Lakes Chemical Corporation. 2000. Analytical method verification for the determination of pentabromodiphenyl oxide (PeBDPO) in soil to support an acute toxicity study with the earthworm. Final report. Project No. 298C-117, Wildlife International, Ltd., February. 
[98] Great Lakes Chemical Corporation. 1984. 90-day dietary study in rats with pentabromodiphenyl oxide (DE-71). Final report. Project No. WIL-12011,WIL Research Laboratories, Inc.

[99] Sjödin A. Occupational and dietary exposure to organohalogen substances, with special emphasis on polybrominated diphenyl ethers. 2000. Doctoral dissertation, Stockholm University.

[100] Zhou T, Ross DG, DeVito MJ, Crofton KM. Effects of short-term in vivo exposure to polybrominated diphenyl ethers on thyroid hormones and hepatic enzyme activities in weanling rats. Toxicology Science 2001;61: 76-82.

[101] Norris JM, Ehrmantraut JW, Gibbons CL, Kociba RJ, Schwetz BA, Rose JQ, Humiston CG, Jewett GL, Crummett WB, Gehring PJ, Tirsell JB, Brosier JS. Toxicological and environmental factors involved in the selection of decabromodiphenyl oxide as a fire retardant chemical. Journal of Fire Flammants Combustible Toxicology 1974;1: 52-77.

[102] Breslin WJ, Kirk HD, Zimmer MA. Teratogenic evaluation of a polybromodiphenyl oxide mixture in New Zealand White rabbits following oral exposure. Fundaments of Applied Toxicology 1989;12: 151-157. 